\title{
A NOVEL HYBRID MULTI-CRITERIA DECISION-MAKING MODEL TO ASSESS A STAIRS SHAPE FOR DWELLING HOUSES
}

\author{
Zenonas TURSKIS ${ }^{\mathrm{a}}$, Birute JUODAGALVIENË ${ }^{\mathrm{b}}$ \\ a Department of Construction Technology and Management, Faculty of Civil Engineering, Vilnius Gediminas \\ Technical University, Saulètekio ave. 11, LT-10223, Vilnius, Lithuania \\ ${ }^{b}$ Department of Graphical Systems, Faculty of Fundamental Sciences, Vilnius Gediminas Technical University, \\ Sauletekio ave. 11, LT-10223, Vilnius, Lithuania
}

Received 20 Apr 2016; accepted 28 Sep 2016

\begin{abstract}
The paper presents a novel approach to solve problem of stairs shape assessment for two-story individual dwelling houses. Selection among available shapes and construction of stairs is a multi-criteria decision-making problem in nature. It depends on a set of different conflicting criteria, that have different optimisation direction, different measurement units. There is determined the set of the main criteria to assess the alternatives is as follows: Stairwell Area, The Total Area of Climbing, "Climbing Lane" Area, The Cost of Stairs, and Ergonomics. A novel original hybrid MCDM (multi-criteria decision-making) model, which based on ten different multi-criteria decision-making methods: Game Theory, AHP, and SAW, Multiplicative Exponential Weighting, TOPSIS, and EDAS, ARAS, Full Multiplicative form, Laplace Rule, and Bayes Rule, is presented.
\end{abstract}

Keywords: stairs, single-family houses, Multi-Criteria Decision-Making, MADM, Game Theory, AHP, SAW, Multiplicative Exponential Weighting, TOPSIS, EDAS, ARAS, Full Multiplicative form, Laplace Rule, Bayes Rule.

\section{Introduction}

Construction activity is one of the most resource consuming sectors in EU. Everybody knows that on the one hand, human behaviour and wellbeing is influenced by building's architecture. It has a big interaction with the building forms and their organization on the land area. On the other hand, building' characteristics have a major impact on the environmental and energy performance of buildings. High consumption of natural sources, high amount production of industrial wastes and environmental pollution are some of the factors, which have a major impact on the environment and is a major consumer of a wide range of naturally occurring and synthesized resources. The second top cause of energy consumption in residential building after heating is the building materials, which can represent more than $2 / 3$ of the heating consumption. The design, construction and running costs are in the ratio 0.1: $1: 3-4$ for dwelling houses in Lithuania.

The resource efficiency increment is possible by the reduction in use of energy and materials (Medineckiené et al. 2015). A sustainable building constructed of materials that could decrease environmental impacts, such as energy usage, during the lifecycle of the building. Highefficiency building's constructions increase the efficiency of the building and thus reduce the energy consumption in the operational stage. Designing low-energy architecture to minimize energy consumption requires thoughtful articulation of the shape and form of a building. However, the constructor as well as the design professionals must have an appreciation and full understanding of the technological complexities often associated with innovative designs in order to provide a safe and sound facility. Floor plan design is commonly governed by considerations of comfort and accessibility. The layout of architectural spaces in the plane is known as the spatial allocation problem. A house geometric characteristics depends on a set of selection criteria. Different generations of people are choosing different criteria. Therefore, criteria set and significances of criteria are dependent on the nature of problem, problem's goals, responding to the conditions in the environment, and decision-makers preferences.

Lot of tools were developed to facilitate the work of designers and make their work more efficient. For example, Graphisoft introduced "Virtual Building Solution" known as ArchiCAD in 1986 (Kmethy 2008). This software allowed architects to create virtual, three-dimensional representations of their projects. This important because architects and engineers then are able to store large amounts of datasets 'within' the building model including the geometry of the building and spatial data, as well as

Corresponding author: Zenonas Turskis

E-mail: zenonas.turskis@vgtu.lt 
the properties and quantities of the components used in the design.

Stairs are a functional part of any multi-level building but they are also an opportunity for creative design. The staircase, when carefully designed and built, adds dignity and charm to a home. Nevertheless, statistics show that stairways are the cause of the greatest number of accidents in the home. A stair fall can be initiated by many conditions or events, some related to the geometric characteristics but also to other more independent causes condition of a tread or walking surface. Stairs must be adapted to meet many requirements to fit into a particular building and be as comfortable to use as possible.

Only few of research papers present studies about stairs design in public buildings. Parameters of the stairs not discussed, because the norms determines them. The objects of researches are security of evacuation (Noren et al. 2014; Huo et al. 2016; Lei et al. 2012) and faire safety (Kesler et al. 2016). Ding et al. (2015), based on computer modelling and simulation, the problem of evacuation strategies, presented a computer model to investigate combination of stairs and elevators for high-rise buildings. Human comfort in a private environment affects the overall health and performance. The Architect's decision-making for more energy efficient building form often based on rules of thumb. Historically, the rule of thumb regarding passive solar building design suggests that form and orientation matter to overall energy performance (Hemsath, Bandhosseini 2015).

Several of research papers deals with stairs in singlefamily houses. They examines the problems related to medicine (impact on human movement apparatus) (Peng et al. 2016) and aging (Huang et al. 2014; Alcock et al. 2015). In addition, the stairs is an area where the number of accidents is higher than one imagined. Therefore, in the study choice of the stairs geometric parameters should be related to multi-criteria such as aesthetics, surface area, climbing convenience, and construction technology.

\section{Object description}

Stairs are one of the more difficult items to fit into a home. The location of stairs heavily influences the remainder of the floor plan. Various principles have been proposed over the years to limit the space required for stairs, to determine form of them, or to regain some of the lost space for other uses.

The first principle is lower energy consumption for the time. It is better to move inclined plane rather than the vertical. According to the Energy Conservation Law, the work done is the same, because it depends only on the difference in height between the levels and distribution in time here is more sustainable because of longer road.

The second principle - anthropocentric formulated as follows: "stairs - for man, and not man - for stairs". Vertical, according to contemporary designers, in meeting the requirements of ergonomic, divided into discrete sections-modules corresponding to the main anthropocen- tric parameter - human step. Each of the multi-levels (tier planes) must have been a small horizontal area to counter human foot during walking. The ratio between the height and width of these low levels can be different depending on the angle of inclination of the stairs and construction. Ergonomics expressed by the formula to select the abovementioned values (step height and width):

$$
S=a+2 h,
$$

where $a$-width of a step, $h$ - height of the stage, and $S$ - the average length of human step $(600-640 \mathrm{~mm})$.

Noren et al. (2014) used Eq. (1), which originally is presented by Jacąues-Francois Blondel in 1672, to compare evacuation by stairs. Beside this, it is useful to assess movement convenience on stairs with a different angle of inclination of stairways.

All residential buildings' homeowners (projects' architects) are solving a problem of geometric characteristics and other criteria selection for internal staircase (when building has ground level and first floor). Furthermore, the problem is significant when designing a new or renovating an existing building. Traditionally, Lithuanian residents in constructing own houses prefer bearing wall construction system. Structural designers use different criteria sets to select structural solutions (Šaparauskas et al. 2011). These solutions enable satisfying clients' needs, providing a high structural quality, and performance while pursuing sustainability (Zavadskas et al. 2014a).

It is well known that the frame structural system of building installed up to 10 times faster, then common masonry systems. The reason of such selection still rare as Lithuanians prefer it not only for tradition, but also for the stability of the house (although, in authors' opinion the most important is the vapour barrier film on the indoor side of the negative effect). Such wall structural systems of house in most cases planned to live with the family, then get old, and, maybe, even live with grandchildren. Therefore, the owners of the house (the stairs) (Fig. 1) need to select among available forms of stairs and to decide what and how often they move (different options are for a child, an old man, or a young and energetic human.

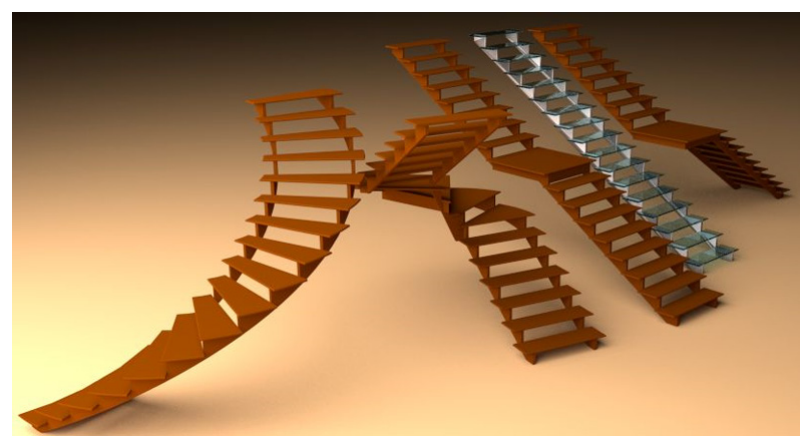

Fig. 1. Different forms of stairs (stairways and steps) 


\subsection{Graphics of stair-shapes}

There are available eight main stair shapes for singlefamily houses (Table 1). It is challenge for stakeholders and designers to select the best shape of stairs. The criteria set, which determines performance of stairs, should to be determined. The construction types usually chosen based on the designers' and builders' opinions and experience, regardless of the specific engineering-geological conditions and features of the house structure (Sušinskas et al. 2014). The criteria have different optimization direction and are conflicting one to other. Satisfying one of these criteria comes at the expense of another. There does not exist a single solution for a multi-criteria decision-making problem that simultaneously optimizes each criterion. In that case, the objective functions said to be conflicting. A solution is Pareto optimal or Pareto efficient, if none of the objective functions can be improved in value without degrading some of the other objective values. For these reasons, this problem stair shape selection problem is a typical multi-criteria decision-making task. Selecting of a particular MCDM method depends on a problem's characteristics, and is based on the decision maker's preference.

\subsection{The AHP method for criteria weight elicitation}

A fundamental problem of decision theory is how to derive weights for a set of activities according to importance. Importance usually judged according to several criteria (Saaty 1980). There is no "best" method for choosing weights. A variety of methods proposed for eliciting weights. The review of past works has shown that Analytic Hierarchy Process (AHP) seems to be the most common MCDM method used in civil engineering decision problems.

Saaty recommends a nine level dominance scale, which Saaty described by appeal to Miller's (Miller 1956) magical number seven plus two (Table 2) (Saaty 1980). There are $n(n-1) / 2$ judgments required to develop a $n \times n$ judgment matrix, since reciprocals automatically assigned in each pair-wise comparison.

Table 1. Main stair shapes for single flat dwelling houses



Table 2. Initial data for pairwise comparison

\begin{tabular}{|c|c|c|c|c|c|c|c|c|}
\hline \multicolumn{9}{|c|}{ Saaty's classical nine-point scale of relative importance } \\
\hline & $\begin{array}{l}\text { Diagonal } \\
\text { elements } \\
\quad i=j\end{array}$ & $\begin{array}{c}C_{i} \text { and } \\
C_{j} \text { are } \\
\text { equally } \\
\text { important }\end{array}$ & $\begin{array}{c}C_{i} \text { is } \\
\text { weakly more } \\
\text { important } \\
\text { than } C_{j}\end{array}$ & $\begin{array}{l}C_{i} \text { is } \\
\text { strongly more } \\
\text { important than }\end{array}$ & $\begin{array}{c}C_{i} \text { is } \\
\text { demonstratively } \\
\text { more important } \\
\text { than } C_{j}\end{array}$ & $\begin{array}{c}C_{i} \text { is absolutely } \\
\text { more important } \\
\text { than } C_{j}\end{array}$ & $\begin{array}{l}\text { Compromise } \\
\text { between two } \\
\text { judgments }\end{array}$ & $\begin{array}{l}\text { If element } C_{j} \\
\text { dominates over } \\
\text { element } C_{i}\end{array}$ \\
\hline$a_{i j}$ & 1 & 1 & 3 & 5 & 7 & 9 & $2,4,6,8$ & $a_{i j}=1 / a_{i j}$ \\
\hline \multicolumn{9}{|c|}{ Random Consistency Indices $(I R)$ for different number of criteria $(n)$} \\
\hline$n$ & 1 & 2 & 3 & 4 & 5 & 6 & 7 & 8 \\
\hline$R I$ & 0 & 0 & 0.58 & 0.9 & 1.12 & 1.24 & 1.32 & 1.41 \\
\hline
\end{tabular}




\section{Criteria set}

The article presents the criteria set for the selection among sixteen different shapes of steps, which vary in form (5 different shapes), stage height, and width of the variable-step staircase turns. There are selected is the most widely used steps in Lithuania $-170 \times 290 \mathrm{~mm}$ and more comfortable steps $153 \times 300 \mathrm{~mm}$. There are 18 and 20 steps respectively in order to ensure the same height of a floor, which is equal to $3060 \mathrm{~mm}$.

Staircase area. This area includes stairs, landings (if any) and the space between the two flights of stairs, in the case of any other functional purpose this gap does not perform. The stairs shape and dimensions (if it is necessary to carry furniture) should to be of appropriate dimensions. The staircases area should to have proper thermal insulation in cold season of year. Total climbing area. In four cases out of sixteen $\left(\mathrm{L}_{1 \mathrm{a}}, \mathrm{L}_{1 \mathrm{~b}}\right.$, $\mathrm{L}_{5 \mathrm{a}}, \mathrm{L}_{5 \mathrm{~b}}$ ) the present total climbing area of stairs equals to the stairwell area. This value differs only in case when width of steps is varying.

Despite estimates of material resources and work force demand, the ergonomic and aesthetic requirements should be taking into account.

"Climbing lane" area. This lane area determines area, which is convenient for climbing stairs human foot. When all the steps are the same width, this area does not differ from the total climbing area. This value is searchable only on variable-width steps. Usually man climbs the stairs perpendicular tier working edge. Asking big enough, but a reasonable range of human-step length: $570 \geq S \geq 750$ (mm). The research deals with two height and width sizes stairs. The first stairs (1): line of climbing from $a=290 \mathrm{~mm}, h=170 \mathrm{~mm}$, the second stairs (2): $a=300 \mathrm{~mm}, h=153 \mathrm{~mm}$. According to Blondel's formula to calculate the relative width of the stairs (handy foot) for the minimum $(570 \mathrm{~mm})$ and maximum $(750 \mathrm{~mm})$ length of human-step:

$$
\begin{gathered}
b_{\text {min }}=570-2 \times 170=230, \text { and } \\
b_{\text {max }}=750-2 \times 170=410(\mathrm{~mm}) ; \\
b_{\text {min }}=570-2 \times 153=264, \text { and } \\
b_{\text {max }}=750-2 \times 153=444(\mathrm{~mm}) .
\end{gathered}
$$

The lines drawn parallel to the working edge step of stairs according to calculated values, indicating the points of intersection with the next step. This operation repeated for all steps of varying width. The set points connected by a broken line, and the resulting polygon hatched. The resulting figure is named "climbing lane" (Fig. 2). The wider the band and the comfortable distance it is from the railing, the more comfortable is to climb the stairs.

Costs. This case study includes only the installation price of the stairs (operation costs are ignored). The same load-bearing elements are selected in all considered forms of stairs: metal tube beams $100 \times 150 \times 5 \mathrm{~mm}$, the same cross-section beams and ash steps finishing. In each case, there are taken into account installing works as follows: stairs beams preparation, welding, priming, painting, staining and lacquering steps and steps installation on the stairs (metal beams angles are used).

Ergonomics. In short, ergonomics is the science of the comfortable environment. In most cases, ergonomics deals with objects and equipment, but ergonomically optimized processes are object of this science. This done by examination of how to change the process to match the user's requirements. It must be comfortable as possible to use and most importantly - safe.

According to statistics disaster on the stairs occurs two times more than on a slippery bath or sauna floor. This happens because of the steep stairs, handrails lack of intermediate courts lack or defect steps (Sheehan, Gottschall 2012). Study by Novak et al. (2016) highlights the definite need for safer stair design standards to minimize the risk of falls and increase stair safety across the lifespan.

Generally, the standards are drawn up taking into account the ergonomic requirements of the stairs (STR 2.02.01:2004; STR 2.02.09:2005, Neufert, E., Neufert, P. 2012).The comfort of a stairs depends on the width and height of steps. As judged by climbing the stairs down, the most important ergonomic criteria are depth and width of steps. Therefore, designers offer to evaluate the criteria of the stairs. How often will use stairs or carried by them dirt to the floor? There should to be choose the retracted handrails in case when in the house are living or will be living children and instead balusters and instead should be used stringers. It is important to ensure enough height of installing stairs whole (the head of climbing man should not to exceed the constructions of stairs).
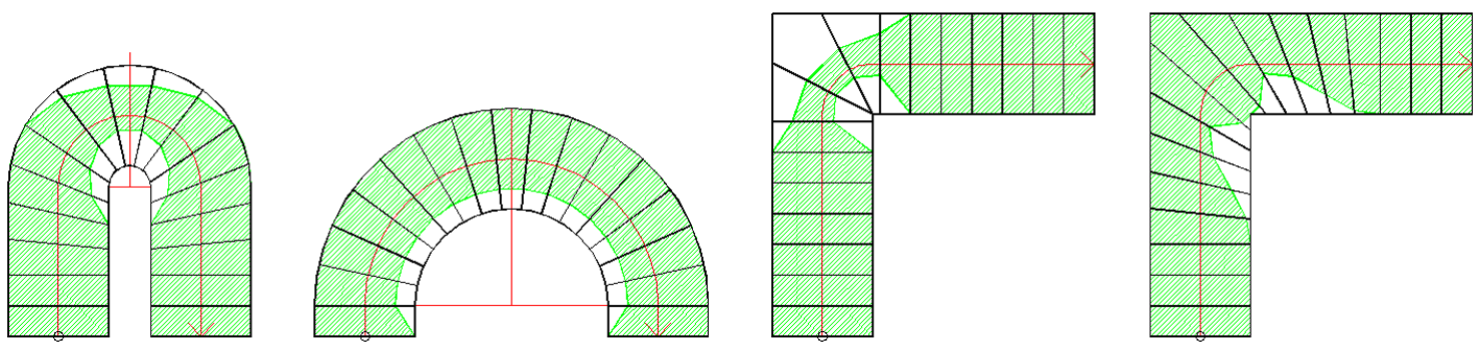

Fig. 2. Climbing lane width of a different forms of stairs 
Lighting of stairs depends on the general assumptions and ideas of the house project. Special project part of stairs lighting will make them more beautiful and safer. Illuminated stair marches, steps, handrails are serving as interior design as well as security means.

The traditional $\mathrm{L}_{2 b}$ type stairs are of the safest form (among considered in this case study) both for climbing as young as well as old human. However, this type of stairs requires the largest value of floor.

Aesthetics. Regularly, stairs are one of the most important interior accents of the house. A customer has to decide what type of stairs (price of stairs) he/she wants. An architect must perfectly adapt the stairs to the available space, taking into account their functionality, safety and importance to the interior. Today, exits wide variety of available types and constructions of beautiful and stylish stairs. In any case, if adult man or children climb them the stairs must be safe. For example, despite the fact that the spiral stairs (which not considered in the case study) are one of the most attractive, they are most not convenient and dangerous stairs. The aesthetic view of stairs is influenced by a design of the stairs (wooden, metal or reinforced concrete strings), steps attachment to the strings, risers' installation or lack, selected material, handrails construction, lighting and form of stairs (investigated in the case study). Of course, the stairs form determined not only by the desire to have one or other form of stairs. It influenced by building bearing constructions, walls and building plans. For example, if the contour line of walls is not only strict beeline, other types of stairs shape used. The arc-shaped wall space is perfect for $\mathrm{L}_{3}$, $\mathrm{L}_{4}$ and $\mathrm{L}_{5}$ stairs shape, but the usual rectangular shape of house-type walls hardly fit the shape of the interior stairs.

Technological properties of construction. In principle, all the stairs in single-family houses are non-standard products. It is great, when there is no enough space of floor for installing stairs. Stair hole must meet the stair configuration (shape). The surface must be specially prepared and plated to look attractive stairs and a longer service life. There is simple rule: the more attractive stairs plan, the more difficult they installed. Of course, to install steps with arched shape and variable-width will take more time, but after all, this leads out-off costs.

Based on the research, it can be stated that selection of stairs shape is multi-criteria decision-making problem. Each performance criterion of stairs has own significance for decision-maker.

\section{Multiple criteria assessment of alternatives}

In order to perform reasoned assessment of various alternatives and offer appropriate solutions, the multiplicity of data regarding alternative economic variables, and technological innovativeness shall be analysed (Štreimikienè et al. 2016). However, most assessment methods are seeking to find how to make the most economic construction decisions, and most of all these decisions are intended only for economic objectives (Sivilevičius et al.
2008). Multi-criteria decision-making (MCDM) (also called multi-objective decision-making with finite alternatives, or multi-attribute decision-making with finite set of discrete alternatives) is an important component of modern Operations Research science. MCDM methods have substantially evolved since 1970 s, and had various types of real world applications (Kaplinski et al. 2014). Dozens of MCDM models developed for evaluating the performance of the available alternatives can be used for selecting the most suitable alternative from a given finite set of options based on a set of attributes (Turskis et al. 2016). Essentially, MCDM involves making preference decisions over the available set of alternatives that characterized by multiple, usually conflicting, attributes. Solution of problems using MCDM are used in developing areas of civil engineering such as design of sustainable and energy efficient buildings, building information modelling, and assurance of security and safety of built property (Antucheviciene et al. 2015). Different construction of buildings issues are analysed by applying a single MCDM method or aggregation of methods (Zavadskas et al. 2015b). From the perspective of a resident of a building, an ideal situation is an indoor environment that satisfies all the residents (i.e. they have no complaints) and does not unnecessarily increase the risk or severity of illness or injury (Zavadskas et al. 2009). The design of an effective constructions of a building require focusing on rationality throughout the entire development since the definition of needs and goals to the very end-of-life stage of the building (Zavadskas et al. 2015a).

Most of multi-attribute decision-making methods share a common number of steps as follows:

1. Define the relevant goals;

2. Determine the alternatives to be evaluated;

3. Identify the relevant attributes for evaluating the alternatives;

4. Determine weights (relative importance) of the attributes;

5. Score each attribute of each alternative;

6. Select a scoring method and calculate the multi-attribute utilities of various options;

7. Perform post-evaluation analysis.

The Analytic Hierarchy Process (AHP) method selected to determine relative significance (weights) of criteria (Saaty 1980). The essence of the process is decomposition of a complex problem into a hierarchy with goal (objective) at the top of the hierarchy, criterions, and sub-criteria at levels and sub-levels of the hierarchy, and decision alternatives at the bottom of the hierarchy. In the standard AHP method model the decision maker judgments are organized into pair wise comparison matrices at each level of the hierarchy. Five high-skilled experts (civil engineers and architects having $\mathrm{PhD}$ degree) made pair-wise comparisons of criteria importance and were determined criteria weights as is shown in Table 3 and Figure 3. 


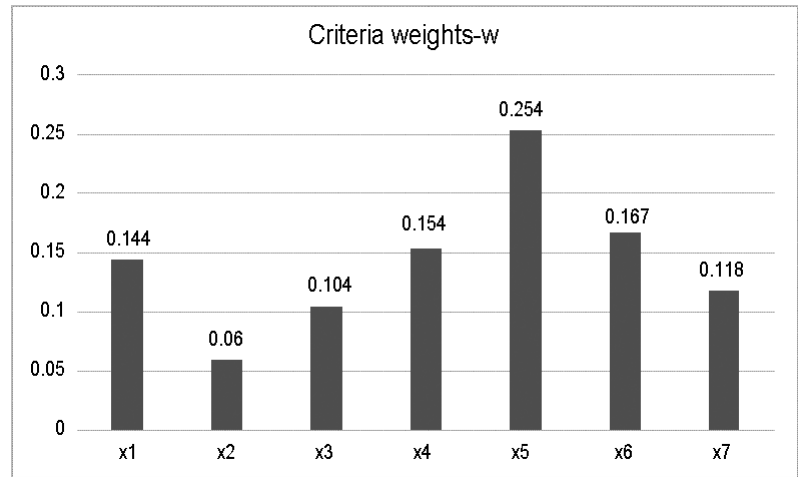

Fig. 3. Criteria weights for stairs shape selection

It is obvious that one of the criteria is very important $\left(x_{5}\right)$, five of the criteria are of medium importance and one criterion $\left(x_{2}\right)$ is less important.

The methodology of decision-making known as multi-criteria decision-making abbreviated to MCDM (Hwang, Yoon 1981; Xu 2015). Decision-maker having the system of criteria, weights of criteria, criteria values formed initial decision-making matrix (Table 3 ) and, in order to rank alternatives and select the best alternative. The typical MCDM problem is concerned with the task of ranking a finite number of decision alternatives, each of which explicitly described in terms of different decision criteria, which have taken into account simultaneously.

In the MCDM of the discrete optimization problem, any problem represented by the decision-making matrix
(DMM) of preferences for $m$ feasible alternatives (rows) rated on $n$ criteria (columns):

$$
X=\left[\begin{array}{ccccc}
x_{01} & \cdots & x_{0 j} & \cdots & x_{0 n} \\
\vdots & \ddots & \vdots & \ddots & \vdots \\
x_{i 1} & \cdots & x_{i j} & \cdots & x_{i n} \\
\vdots & \ddots & \vdots & \ddots & \vdots \\
x_{m 1} & \cdots & x_{m j} & \cdots & x_{m n}
\end{array}\right] ; \quad i=\overline{0, m} ; j=\overline{1, n}
$$

where $m$ - number of alternatives, $n$ - number of criteria describing each alternative, $x_{i j}$ - value representing the performance value of the $i$ alternative in terms of the $j$ criterion, $x_{0 j}$ - optimal value of $j$ criterion.

Integration of different criteria values to one optimality criterion performed by applying 10 different MCDM methods (Zavadskas et al. 2014b) as follows:

- The Method of Evaluation Based on Distance from Average Solution (EDAS) (Keshavarz Ghorabaee et al. 2015);

- Simple Additive Weighting (SAW) (MacCrimon 1968; Antuchevičienè et al. 2015; Tupènaite et al. 2010);

- Multiplicative Exponential Weighting (MEW) (Antuchevičienè et al. 2015);

- The Technique for Order of Preference by Similarity to Ideal Solution (TOPSIS) (Hwang, Yoon 1981; Zavadskas et al. 2015c; Tupenaite et al. 2010) (with equal weights (Table 6) for all criteria and with different criteria weights (Table 5));

- Additive Ratio Assessment (ARAS) method (Zavadskas, Turskis 2010);

Table 3. Considered stair alternatives

\begin{tabular}{|c|c|c|c|c|c|c|c|c|}
\hline \multirow[b]{2}{*}{ Alternatives } & & \multicolumn{7}{|c|}{ Attributes } \\
\hline & & $\begin{array}{l}\text { Staircase } \\
\text { area, } \mathrm{m}^{2}\end{array}$ & $\begin{array}{c}\text { Total climbing } \\
\text { area, } \mathrm{m}^{2}\end{array}$ & $\begin{array}{l}\text { Total climbing } \\
\text { area, } \mathrm{m}^{2}\end{array}$ & $\begin{array}{l}\text { Cost, } \\
\text { Eur. }\end{array}$ & Ergonomics & $\begin{array}{l}\text { Aesthetic } \\
\text { view }\end{array}$ & Technologic \\
\hline & & $x_{1}$ & $x_{2}$ & $x_{3}$ & $x_{4}$ & $x_{5}$ & $x_{6}$ & $x_{7}$ \\
\hline Weights $-w$ & & 0.144 & 0.060 & 0.104 & 0.154 & 0.254 & 0.167 & 0.118 \\
\hline Optimum & & $\min$ & $\max$ & $\max$ & $\min$ & $\max$ & $\max$ & $\max$ \\
\hline $\mathrm{L}_{1 \mathrm{a}}$ & $A_{1}$ & 4.680 & 4.680 & 4.680 & 1596.68 & 0.120 & 0.130 & 0.345 \\
\hline $\mathrm{L}_{1 \mathrm{~b}}$ & $A_{2}$ & 5.420 & 5.420 & 5.420 & 1775.66 & 0.120 & 0.130 & 0.345 \\
\hline $\mathrm{L}_{2 \mathrm{a}}$ & $A_{3}$ & 7.390 & 4.410 & 4.410 & 2623.09 & 0.180 & 0.035 & 0.160 \\
\hline $\mathrm{L}_{2 b}$ & $A_{4}$ & 8.190 & 5.130 & 5.130 & 2788.75 & 0.240 & 0.035 & 0.160 \\
\hline $\mathrm{L}_{3 \mathrm{a}}$ & $A_{5}$ & 5.040 & 4.640 & 3.750 & 3073.16 & 0.090 & 0.074 & 0.100 \\
\hline $\mathrm{L}_{3 \mathrm{~b}}$ & $A_{6}$ & 5.850 & 5.520 & 4.470 & 3161.49 & 0.040 & 0.074 & 0.100 \\
\hline $\mathrm{L}_{4 \mathrm{a}}$ & $A_{7}$ & 5.330 & 4.700 & 3.880 & 3073.16 & 0.060 & 0.074 & 0.033 \\
\hline $\mathrm{L}_{4 \mathrm{~b}}$ & $A_{8}$ & 6.210 & 5.430 & 4.370 & 3161.49 & 0.040 & 0.074 & 0.033 \\
\hline $\mathrm{L}_{5 \mathrm{a}}$ & $A_{9}$ & 4.700 & 4.700 & 4.100 & 2561.11 & 0.090 & 0.497 & 0.053 \\
\hline $\mathrm{L}_{5 \mathrm{~b}}$ & $A_{10}$ & 5.450 & 5.450 & 4.420 & 2634.67 & 0.060 & 0.497 & 0.053 \\
\hline $\mathrm{L}_{6 \mathrm{a}}$ & $A_{11}$ & 5.310 & 4.410 & 5.310 & 2224.28 & 0.040 & 0.265 & 0.160 \\
\hline $\mathrm{L}_{6 \mathrm{~b}}$ & $A_{12}$ & 6.020 & 5.120 & 6.020 & 2389.37 & 0.170 & 0.265 & 0.160 \\
\hline $\mathrm{L}_{7 \mathrm{a}}$ & $A_{13}$ & 4.890 & 4.890 & 4.210 & 2335.50 & 0.060 & 0.265 & 0.093 \\
\hline $\mathrm{L}_{7 \mathrm{~b}}$ & $A_{14}$ & 5.650 & 5.650 & 4.960 & 2508.98 & 0.040 & 0.265 & 0.093 \\
\hline $\mathrm{L}_{8 \mathrm{a}}$ & $A_{15}$ & 4.890 & 4.890 & 4.510 & 2446.71 & 0.060 & 0.265 & 0.055 \\
\hline $\mathrm{L}_{8 \mathrm{~b}}$ & $A_{16}$ & 5.650 & 5.650 & 4.810 & 2628.30 & 0.040 & 0.265 & 0.055 \\
\hline
\end{tabular}


- Full Multiplicative Utility function (FM) (Bridgman 1922);

- The problem solved by applying LEVI program. The program includes discrete two person Game Theory methods (Turskis et al. 2009) with zero payment sum and TOPSIS method. First, the problem solved by applying Bayes rule and then Laplace rule is applied (Tables 4 and 5).

The problem's solution results are condensed and presented in Tables 4, 5, and 6. Ranks of alternatives (when weights of criteria are considered) presented in Figure 4.

To check consistency of alternatives ranking Expert judgement method is applied (Medineckienè et al 2015). The methods there considered as experts and alternatives as criteria.

The following values of coefficients calculated:

- The coefficient of concordance $\mathrm{W}=0.938$;

- The significance of the concordance coefficient (no related ranks) $\chi_{\alpha, v}^{2}=98.5$;

Table 4. Integrated table of results

\begin{tabular}{c|c|c|c|c|c|c|c|c|c}
\hline & \multicolumn{1}{|c}{ Value of Utility function determined by different methods } \\
\cline { 2 - 10 } & Bayes & Laplace & SAW & MEW & $\begin{array}{c}\text { TOPSIS } \\
(-\mathrm{w})\end{array}$ & $\begin{array}{c}\text { TOPSIS } \\
(+\mathrm{w})\end{array}$ & $\mathrm{FM}$ & EDAS & ARAS \\
\hline Alternatives & $\mathrm{K}$ & $\mathrm{K}$ & $\mathrm{K}$ & $\mathrm{K}$ & $\mathrm{K}$ & $\mathrm{K}$ & $\mathrm{K}$ & $\mathrm{U}$ & $\mathrm{K}$ \\
\hline$A_{1}$ & 0.085 & 0.698 & 0.7168 & 0.9395 & 0.563 & 0.468 & 0.003277 & 1.3575 & 0.6673 \\
\hline$A_{2}$ & 0.074 & 0.631 & 0.7021 & 0.9377 & 0.553 & 0.464 & 0.003412 & 1.3458 & 0.6560 \\
\hline$A_{3}$ & 0.058 & 0.344 & 0.5643 & 0.8924 & 0.393 & 0.476 & 0.000208 & 0.7354 & 0.5401 \\
\hline$A_{4}$ & 0.088 & 0.449 & 0.6332 & 0.9018 & 0.466 & 0.574 & 0.000319 & 1.1837 & 0.6240 \\
\hline$A_{5}$ & 0.037 & 0.321 & 0.4818 & 0.8813 & 0.232 & 0.232 & 0.000155 & 0.0298 & 0.4164 \\
\hline$A_{6}$ & 0.026 & 0.326 & 0.4299 & 0.8561 & 0.179 & 0.122 & 0.000082 & -0.3548 & 0.3496 \\
\hline$A_{7}$ & 0.029 & 0.288 & 0.4229 & 0.8519 & 0.149 & 0.133 & 0.000034 & -0.3870 & 0.3429 \\
\hline$A_{8}$ & 0.023 & 0.295 & 0.3977 & 0.8389 & 0.120 & 0.086 & 0.000025 & -0.5638 & 0.3133 \\
\hline$A_{9}$ & 0.071 & 0.507 & 0.6402 & 0.9187 & 0.460 & 0.450 & 0.000787 & 1.0107 & 0.5901 \\
\hline$A_{10}$ & 0.060 & 0.487 & 0.5995 & 0.9042 & 0.435 & 0.402 & 0.000550 & 0.7584 & 0.5437 \\
\hline$A_{11}$ & 0.046 & 0.424 & 0.5617 & 0.8988 & 0.370 & 0.283 & 0.000697 & 0.4486 & 0.4906 \\
\hline$A_{12}$ & 0.074 & 0.513 & 0.6962 & 0.9462 & 0.524 & 0.574 & 0.003201 & 1.4434 & 0.6634 \\
\hline$A_{13}$ & 0.046 & 0.408 & 0.5518 & 0.9021 & 0.324 & 0.280 & 0.000552 & 0.3876 & 0.4799 \\
\hline$A_{14}$ & 0.029 & 0.413 & 0.5258 & 0.8881 & 0.307 & 0.250 & 0.000404 & 0.2221 & 0.4491 \\
\hline$A_{15}$ & 0.045 & 0.405 & 0.5392 & 0.8941 & 0.301 & 0.269 & 0.000334 & 0.2886 & 0.4624 \\
\hline$A_{16}$ & 0.029 & 0.395 & 0.5058 & 0.8790 & 0.282 & 0.239 & 0.000221 & 0.0940 & 0.4266 \\
\hline & & & & & & & & \\
\hline
\end{tabular}

Table 5. Ranking of alternatives when criteria weights are considered

\begin{tabular}{|c|c|c|c|c|c|c|c|c|c|}
\hline & \multicolumn{7}{|c|}{ Ranks of alternatives determined by different methods } & \multicolumn{2}{|c|}{ Final ranks } \\
\hline & SAW & Bayes & MEW & TOPSIS & EDAS & ARAS & FM & Average & Final \\
\hline$A_{1}$ & 1 & 2 & 2 & 4 & 2 & 1 & 2 & 2.3 & 1 \\
\hline$A_{2}$ & 2 & 3 & 3 & 5 & 3 & 3 & 1 & 3.3 & 3 \\
\hline$A_{3}$ & 7 & 7 & 10 & 7 & 7 & 7 & 12 & 9.5 & 9 \\
\hline$A_{4}$ & 5 & 1 & 7 & 6 & 4 & 4 & 10 & 6.2 & 5 \\
\hline$A_{5}$ & 13 & 13 & 12 & 13 & 13 & 13 & 13 & 15.0 & 13 \\
\hline$A_{6}$ & 14 & 15 & 14 & 14 & 14 & 14 & 14 & 16.5 & 14 \\
\hline$A_{7}$ & 15 & 14 & 15 & 15 & 15 & 15 & 15 & 17.3 & 15 \\
\hline$A_{8}$ & 16 & 16 & 16 & 16 & 16 & 16 & 16 & 18.7 & 16 \\
\hline$A_{9}$ & 4 & 5 & 4 & 2 & 5 & 5 & 4 & 4.8 & 4 \\
\hline$A_{10}$ & 6 & 6 & 5 & 3 & 6 & 6 & 7 & 6.5 & 6 \\
\hline$A_{11}$ & 8 & 9 & 8 & 8 & 8 & 8 & 5 & 9.0 & 7 \\
\hline$A_{12}$ & 3 & 4 & 1 & 1 & 1 & 2 & 3 & 2.5 & 2 \\
\hline$A_{13}$ & 9 & 8 & 6 & 9 & 9 & 9 & 6 & 9.3 & 8 \\
\hline$A_{14}$ & 11 & 11 & 11 & 11 & 11 & 11 & 8 & 12.3 & 11 \\
\hline$A_{15}$ & 10 & 10 & 9 & 10 & 10 & 10 & 9 & 11.3 & 10 \\
\hline$A_{16}$ & 12 & 12 & 13 & 12 & 12 & 12 & 11 & 14.0 & 12 \\
\hline
\end{tabular}


Table 6. Ranking of alternatives when criteria weights are not considered

\begin{tabular}{c|c|c|c|c|c}
\hline & FM & $\begin{array}{c}\text { Laplace } \\
\text { rule }\end{array}$ & $\begin{array}{c}\text { TOPSIS } \\
\text { (with equal weights) }\end{array}$ & Final & Average \\
\hline$A_{1}$ & 2 & 1 & 1 & 1 & 1.33 \\
\hline$A_{2}$ & 1 & 2 & 2 & 2 & 1.67 \\
\hline$A_{3}$ & 12 & 12 & 7 & 11 & 10.33 \\
\hline$A_{4}$ & 10 & 8 & 4 & 7 & 7.33 \\
\hline$A_{5}$ & 13 & 14 & 13 & 13 & 13.33 \\
\hline$A_{6}$ & 14 & 13 & 14 & 14 & 13.67 \\
\hline$A_{7}$ & 15 & 16 & 15 & 15 & 15.33 \\
\hline$A_{8}$ & 16 & 15 & 16 & 16 & 15.67 \\
\hline$A_{9}$ & 4 & 4 & 5 & 4 & 4.33 \\
\hline$A_{10}$ & 7 & 5 & 6 & 5 & 6.00 \\
\hline$A_{11}$ & 5 & 7 & 8 & 6 & 6.67 \\
\hline$A_{12}$ & 3 & 3 & 3 & 3 & 3.00 \\
\hline$A_{13}$ & 6 & 9 & 9 & 8 & 8.00 \\
\hline$A_{14}$ & 8 & 8 & 10 & 9 & 8.67 \\
\hline$A_{15}$ & 9 & 10 & 11 & 10 & 10.00 \\
\hline$A_{16}$ & 11 & 11 & 12 & 12 & 11.33 \\
\hline
\end{tabular}

- Rank of table concordance $\chi_{\text {tabl. }}^{2}=32$ when the importance equal to $1 \%$. The freedom degrees value of a solved problem $v=n-1=16-1=15$. Compatibility of expert judgement (Kendall 1970) is $\chi_{\alpha, v .}^{2}=98.5 \succ \chi_{t a b l .}^{2}=32$. This means that hypothesis about the consent of methods in rankings is accepted.

Final ranks of alternatives are as follows:

$$
\begin{aligned}
& A_{1} \approx A_{12} \succ A_{2} \succ A_{9} \succ A_{4} \succ A_{10} \succ A_{11} \succ A_{13} \succ A_{3} \approx \\
& A_{14} \succ A_{15} \succ A_{16} \succ A_{5} \succ A_{6} \succ A_{7} \succ A_{8} .
\end{aligned}
$$

According to EDAS method:

$$
\begin{aligned}
& A_{12} \succ A_{1} \succ A_{2} \succ A_{4} \succ A_{9} \succ A_{10} \succ A_{3} \succ A_{11} \succ \\
& A_{13} \succ A_{15} \succ A_{14} \succ A_{16} \succ A_{5} \succ A_{6} \succ A_{7} \succ A_{8} .
\end{aligned}
$$

According to TOPSIS method:

$$
\begin{aligned}
& A_{12} \succ A_{9} \succ A_{10} \succ A_{1} \succ A_{2} \succ A_{4} \succ A_{3} \succ A_{11} \succ \\
& A_{13} \succ A_{15} \succ A_{14} \succ A_{16} \succ A_{5} \succ A_{6} \succ A_{7} \succ A_{8} .
\end{aligned}
$$

According to ARAS method:

$$
\begin{aligned}
& A_{1} \succ A_{12} \succ A_{2} \succ A_{4} \succ A_{9} \succ A_{10} \succ A_{3} \succ A_{11} \succ \\
& A_{13} \succ A_{15} \succ A_{14} \succ A_{16} \succ A_{5} \succ A_{6} \succ A_{7} \succ A_{8} .
\end{aligned}
$$

Final ranks of alternatives (when criteria weights are not considered) are as follows (Fig. 5):

$$
\begin{aligned}
& A_{1} \succ A_{2} \succ A_{12} \succ A_{9} \succ A_{10} \succ A_{11} \succ A_{4} \succ A_{13} \succ \\
& A_{14} \succ A_{15} \succ A_{3} \succ A_{16} \succ A_{5} \succ A_{6} \succ A_{7} \succ A_{8} .
\end{aligned}
$$

According to the FM method:

$$
\begin{aligned}
& A_{2} \succ A_{1} \succ A_{12} \succ A_{9} \succ A_{11} \succ A_{13} \succ A_{10} \succ A_{14} \succ \\
& A_{15} \succ A_{4} \succ A_{16} \succ A_{3} \succ A_{5} \succ A_{6} \succ A_{7} \succ A_{8} .
\end{aligned}
$$

According to the Laplace rule:

$$
\begin{aligned}
& A_{1} \succ A_{2} \succ A_{12} \succ A_{9} \succ A_{10} \succ A_{11} \succ A_{14} \succ A_{4} \succ \\
& A_{13} \succ A_{15} \succ A_{16} \succ A_{3} \succ A_{6} \succ A_{5} \succ A_{8} \succ A_{7} .
\end{aligned}
$$

According to the TOPSIS with equal weights:

$$
\begin{aligned}
& A_{1} \succ A_{2} \succ A_{12} \succ A_{4} \succ A_{9} \succ A_{10} \succ A_{3} \succ A_{11} \succ \\
& A_{13} \succ A_{15} \succ A_{14} \succ A_{16} \succ A_{5} \succ A_{6} \succ A_{7} \succ A_{8} .
\end{aligned}
$$

The best four alternatives $A_{1}, A_{2}, A_{9}$ and $A_{12}$ are the same in any case including $\left(A_{1} \approx A_{12} \succ A_{2} \succ A_{9}\right)$ or not including criteria weights to the assessment $\left(A_{1} \succ A_{2} \succ A_{12} \succ A_{9}\right)$. The worst four alternatives

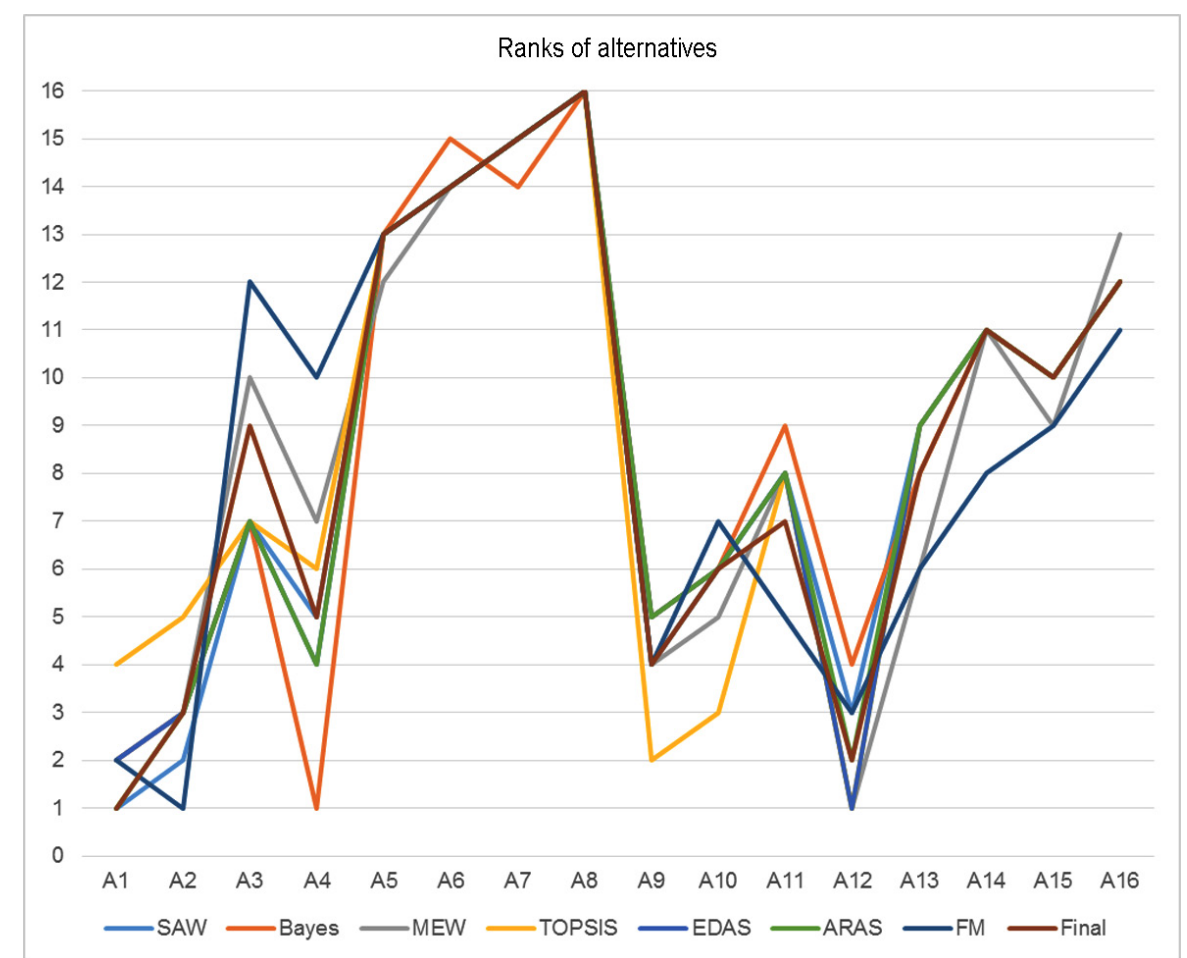

Fig. 4. Ranks of alternatives when weights of criteria are considered 


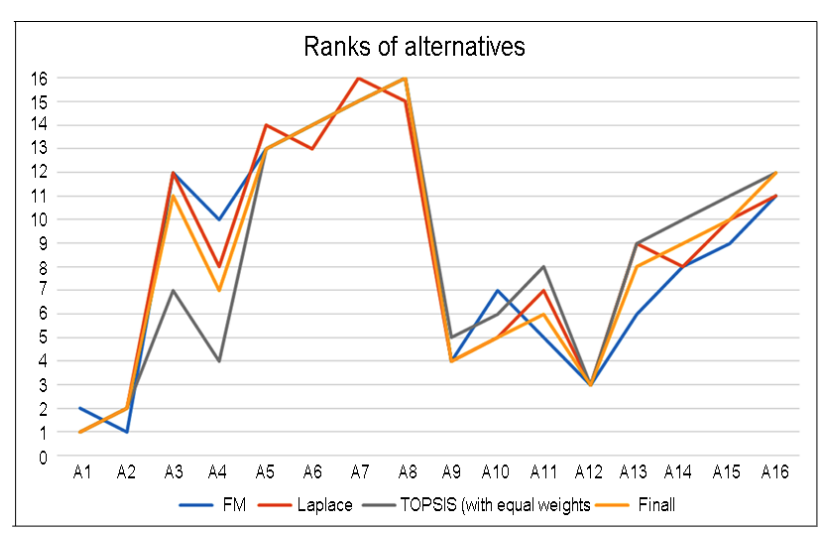

Fig. 5. Ranks of alternatives when are not included weights of criteria

$A_{5}, A_{6}, A_{7}$ and $A_{8}$ are the same in any case including or not including criteria weights to the assessment: $A_{5} \succ A_{6} \succ A_{7} \succ A_{8}$.

The second ranked quarter of alternatives is $A_{4}, A_{10}, A_{11}$ and $A_{13}$, including $A_{4} \succ A_{10} \succ A_{11} \succ A_{13}$ and not including $A_{10} \succ A_{11} \succ A_{4} \succ A_{13}$ criteria weights.

According to the problem's solution results the bestranked alternatives are $A_{1} \approx A_{12}$.

\section{Conclusions}

The suggested problem solution model offers higher prediction reliability, as well as simpler and clearer procedures for analysing building construction alternatives and ranking the attributes in terms of their significance level. The contrast between the results show the applicability of this model as a valuable tool to be used by construction work managers, as well as for decision-making activities and performance evaluation, which contains multiple alternatives and multi-criteria. Applying the MCDM is well-structured selection process among several alternatives. MCDM methods provide a well-structured procedure (sequence of steps) to select the type structure.

The suggested model includes only seven ranked attributes. As a result, practitioners may directly use the model as a means of fast and convenient analysis of building stairs alternatives by applying simple and clearly defined procedures. The algorithm can be easily modified by including new variables, changing their weights, depending on the interested persons and the environment in which decisions are made.

Weighting results show that stakeholders are more concerned with the ergonomics than with the climbing area.

Finally, it should be noted that the Expert Judgement method is proper tool to assess consistency of rankings when different MCDM methods applied (more than 6). The presented hybrid method has a promising future in the decision-making because it offers a methodological basis for decision support.

\section{References}

Alcock, L.; O’Brien, T. D.; Vanicek, N. 2015. Biomechanical demands of the 2-step transitional gait cycles linking level gait and stair descent gait in older women, Journal of Biomechanics 48: 4191-4197.

http://dx.doi.org/10.1016/j.jbiomech.2015.09.020

Antucheviciene, J.; Kala, Z.; Marzouk, M.; Vaidogas, E. R. 2015. Solving civil engineering problems by means of fuzzy and stochastic MCDM methods: Current state and future research, Mathematical Problems in Engineering, Vol. 2015, Article ID 362579, 16 p. http://dx.doi.org/10.1155/2015/362579

Antuchevičienè, J.; Zavadskas, E. K.; Turskis, Z. 2015. Evaluating and selecting a contractor for a construction company by using novel method for multi-attribute analysis: Weighted Aggregated Sum Product ASsessment with Grey values (WASPAS-G) method, Studies in Informatics and Control 24(2): 141-150.

Bridgman, P. W. 1922. Dimensional analysis. New Haven: Yale University Press.

Ding, Y.; Yang, L.; Wenga, F.; Zhijian, Fu Z.; Rao, P. 2015. Investigation of combined stairs elevators evacuation strategies for high rise buildings based on simulation, Simulation Modelling Practice and Theory 53: 60-73. http://dx.doi.org/10.1016/j.simpat.2015.01.004

Hemsath, T. L.; Bandhosseini, K. A. 2015. Sensitivity analysis evaluating basic building geometry's effect on energy use, Renewable Energy 76(C): 526-538.

http://dx.doi.org/10.1016/j.renene.2014.11.044

Huang, H. Y.; Chen, J. S.; Chia-En Huang, C. E. 2014. Toward the gait analysis and control of a powered lower limb orthosis in ascending and descending stairs, Procedia Engineering 79: 417-426.

http://dx.doi.org/10.1016/j.proeng.2014.06.363

Huo, F.; Song, W.; Chen, L.; Liu, C.; Liew, K. M. 2016. Experimental study on characteristics of pedestrian evacuation on stairs in a high-rise building, Safety Science 86: 165-173. http://dx.doi.org/10.1016/j.ssci.2016.02.025

Hwang, C. L.; Yoon, K. S. 1981. Multiple attribute decision making-methods and applications: a state-of-the-art survey. Berlin: Springer.

http://dx.doi.org/10.1007/978-3-642-48318-9

Kaplinski, O.; Peldschus, F.; Tupenaite, L. 2014. Development of MCDM methods - in honour of Professor Edmundas Kazimieras Zavadskas on the occasion of his $70^{\text {th }}$ birthday, International Journal of Computers Communications and Control 9(3): 305-312. http://dx.doi.org/10.15837/ijccc.2014.3.1084

Kendall, M. G. 1970. Rank correlation methods. $4^{\text {th }}$ ed. London: Griffin.

Keshavarz Ghorabaee, M.; Zavadskas, E. K.; Olfat, L.; Turskis, Z. 2015. Multi-criteria inventory classification using a new method of Evaluation Based on Distance from Average Solution (EDAS), Informatica 26(3): 435-451. http://dx.doi.org/10.15388/Informatica.2015.57

Kesler, R. M.; Horn, G. P.; Rosengren, K. S.; Hsiao-Wecksler, E. T. 2016. Analysis of foot clearance in fire fighters during ascent and descent of stairs, Applied Ergonomics 52: 18-23. http://dx.doi.org/10.1016/j.apergo.2015.05.011

Kmethy, G. ArchiCAD versions - ArchicadWiki. FrontPage ArchicadWiki [online], [cited 2 October 2008, 23 August 2009]. Available from Internet: http://www.archicadwiki.com/ArchiCAD\%20versions

Lei, W.; Li, A.; Gao, R.; Wang, X. 2012. Influences of exit and stair conditions on human evacuation in a dormitory, Physica A: Statistical Mechanics and its Applications 391(24): 6279-6286. http://dx.doi.org/10.1016/j.physa.2012.07.044 
MacCrimon, K. R. 1968. Decision making among multiple attribute alternatives: a survey and consolidated approach. RAND Memorandum, RM-4823-ARPA.

Medineckienė, M.; Zavadskas, E. K.; Björk, F.; Turskis, Z. 2015. Multi-criteria decision-making system for sustainable building assessment/certification, Archives of Civil and Mechanical Engineering 15(1): 11-18. http://dx.doi.org/10.1016/j.acme.2014.09.001

Miller, G. A. 1956. The magical number seven, plus or minus two: Some limits in our capacity for processing information, Psychological Review 63(2): 81-97. http://dx.doi.org/10.1037/h0043158

Neufert, E.; Neufert P. 2012. Architect's data. $3^{\text {rd }}$ ed. Blackwell Science.

Noren, J.; Delin, M.; Fridolf, K. 2014. Ascending stair evacuation: what do we know?, Transportation Research Procedia 2: 774-782. http://dx.doi.org/10.1016/j.trpro.2014.09.087

Novak, A. C.; Komisar, V.; Maki, B. E.; Fernie, G. R. 2016. Age-related differences in dynamic balance control during stair descent and effect of varying step geometry, Applied Ergonomics 52: 275-284. http://dx.doi.org/10.1016/j.apergo.2015.07.027

Peng J.; Fey N. P.; Kuiken, T. A.; Hargrove, L. J. 2016. Anticipatory kinematics and muscle activity preceding transitions from level-ground walking to stair ascent and descent, Journal of Biomechanics 49: 528-536. http://dx.doi.org/10.1016/j.jbiomech.2015.12.041

Saaty, T. L. 1980. The Analytic Hierarchy Process. New York: McGraw-Hill.

Šaparauskas, J.; Zavadskas, E. K.; Turskis, Z. 2011. Selection of façade's alternatives of commercial and public buildings based on multiple criteria, International Journal of Strategic Property Management 15(2): 189-203. http://dx.doi.org/10.3846/1648715X.2011.586532

Sheehan, R. C.; Gottschall, J. S. 2012. At similar angles, slope walking has a greater fall risk than stair walking, Applied Ergonomics 43(3): 473-478.

http://dx.doi.org/10.1016/j.apergo.2011.07.004

Sivilevičius, H.; Zavadskas, E. K.; Turskis, Z. 2008. Quality attributes and complex assessment methodology of the asphalt mixing plant, The Baltic Journal of Road and Bridge Engineering 3(3): 161-166.

STR 2.02.01:2004 Gyvenamieji pastatai [Residential buildings], Valstybès žinios, 2004, No. 23-721 (in Lithuanian).

STR 2.02.09:2005 Vienbučiai gyvenamieji pastatai [Singlefamily residential buildings], Valstybès žinios, 2005-0802, No. 93-3464 (in Lithuanian).

Štreimikienè, D.; Šliogeriene, J.; Turskis, Z. 2016. Multi-criteria analysis of electricity generation technologies in Lithuania, Renewable Energy 85: 148-156.

http://dx.doi.org/10.1016/j.renene.2015.06.032

Sušinskas, S.; Turskis, Z.; Stasiškis, A.; Valickas, J.; Rudžionis, Ž. 2014. The efficiency analysis of foundations for buildings with bearing walls for Lithuania ground conditions, Journal of Civil Engineering and Management 20(1): 142-148. http://dx.doi.org/10.3846/13923730.2014.982698

Tupenaitè, L.; Zavadskas, E. K.; Kaklauskas, A.; Turskis, Z.; Seniut, M. 2010. Multiple criteria assessment of alternatives for built and human environment renovation, Journal of Civil Engineering and Management 16(2): 257-266. http://dx.doi.org/10.3846/jcem.2010.30

Turskis, Z.; Daniūnas, A.; Zavadskas, E. K.; Medzvieckas, J. 2016. Multicriteria evaluation of building foundation alternatives, Computer-Aided Civil and Infrastructure Engineering 31(9): 717-729. http://dx.doi.org/10.1111/mice.12202

Turskis, Z.; Zavadskas, E. K.; Peldschus, F. 2009. Multi-criteria optimization system for decision making in construction design and management, Inzinerine Ekonomika-Engineering Economics (1): 7-17.

Xu, Z. 2015. Uncertain multi-attribute decision making: Methods and applications. Berlin Heidelberg: Springer-Verlag. http://dx.doi.org/10.1007/978-3-662-45640-8

Zavadskas, E. K.; Turskis, Z. 2010. A new additive ratio assessment (ARAS) method in multicriteria decision-making, Technological and Economic Development of Economy 16(2): 159-172. http://dx.doi.org/10.3846/tede.2010.10

Zavadskas, E. K.; Kaklauskas, A.; Turskis, Z.; Kalibatas, D. 2009. An approach to multi-attribute assessment of indoor environment before and after refurbishment of dwellings, Journal of Environmental Engineering and Landscape Management 17(1): 5-11. http://dx.doi.org/10.3846/1648-6897.2009.17.5-11

Zavadskas, E. K.; Vilutienè, T.; Turskis, Z.; Šaparauskas, J. 2014a. Multi-criteria analysis of projects' performance in construction, Archives of Civil and Mechanical Engineering 14(1): 114-121. http://dx.doi.org/10.1016/j.acme.2013.07.006

Zavadskas, E. K.; Turskis, Z.; Kildienè, S. 2014b. State of art surveys of overviews on MCDM/MADM methods, Technological and Economic Development of Economy 20(1): $165-179$. http://dx.doi.org/10.3846/20294913.2014.892037

Zavadskas, E. K.; Antuchevičienė, J.; Kapliński, O. 2015a. Multi-criteria decision making in civil engineering: Part I-a state-of-the-art survey, Engineering Structures and Technologies 7(3): 103-113. http://dx.doi.org/10.3846/2029882X.2015.1143204

Zavadskas, E. K.; Antuchevičienė, J.; Kapliński, O. 2015 b. Multi-criteria decision making in civil engineering. Part II - applications, Engineering Structures and Technologies 7(4): 151-167. http://dx.doi.org/10.3846/2029882X.2016.1139664

Zavadskas, E. K.; Turskis, Z.; Bagočius, V. 2015c. Multi-criteria selection of a deep-water port in the Eastern Baltic Sea, Applied Soft Computing 26: 180-192. http://dx.doi.org/10.1016/j.asoc.2014.09.019

Zenonas TURSKIS. Has a PhD and is a chief research worker at Laboratory of Construction Technology and Management at Vilnius Gediminas Technical University, Lithuania. His research interests include building technology and management, decisionmaking theory, computer-aided automation in design and expert systems. He is the author of more than 100 research papers, which are referred in WoS database.

Birutė JUODAGALVIENE். Lecturer at the Department of Graphical Systems, Vilnius Gediminas Technical University (VGTU), Faculty of Fundamental Sciences, Lithuania. Research interests: engineering graphics in building design, building design, information technologies. 